\title{
Careers, Connections, and Corruption Risks: Investigating the Impact of Bureaucratic Meritocracy on Public Procurement Processes
}

\author{
Nicholas Charron, University of Gothenburg \\ Carl Dahlström, University of Gothenburg \\ Mihaly Fazekas, University of Cambridge \\ Victor Lapuente, University of Gothenburg
}

\begin{abstract}
Why do officials in some countries favor entrenched contractors, while others assign public contracts more impartially? This article emphasizes the important interplay between politics and bureaucracy. It suggests that corruption risks are lower when bureaucrats' careers do not depend on political connections but on their peers. We test this hypothesis with a novel measure of career incentives in the public sector-using a survey of more than 18,000 public sector employees in 212 European regions - and a new objective corruption risk measure including over 1.4 million procurement contracts. Both show a remarkable subnational variation across Europe. The study finds that corruption risks are indeed significantly lower where bureaucrats' career incentives exclusively follow professional criteria. In substantial terms, moving EU regions so that bureaucrats' merit and effort would matter as much as in, for example, BadenWüttemberg (90th percentile) could lead to a 13-20 billion Euro savings per year.
\end{abstract}

$\mathrm{C}$ orruption is preventing prosperity across the globe. Analyzing causes of corruption has consequently attracted the attention of scholars of comparative politics, economics, law, and history, and research has made substantial progress during the last two decades (see, e.g., Keefer 2007; La Porta et al. 1999; Persson and Tabellini 2003; Rothstein 2011; Treisman 2007). This article argues that a significant part of the variation in corruption can be explained because corruption risks are systematically lower when bureaucrats' careers are determined by their peers and not by politicians. We analyze public procurement processes on the subnational level across Europe and show that where meritocracy, rather than connections, is decisive for bureaucratic careers, corruption risks are significantly lower.

This finding might not be so surprising since scholars in the field of public administration have long been aware of the importance of meritocracy in recruitment and careers for bureaucrats (Goodnow 1900; Weber [1922] 1978); Wilson 1887). There are indeed several ways in which meritocracy in the public sector could lower corruption risks, including the recruitment and promotion of more motivated and better performing bureaucrats, the development of an esprit de corps, long-term incentives to work hard and prioritize welfare delivery over short-sighted goals, and incen-

Nicholas Charron (nicholas.charron@pol.gu.se) is associate professor of political science, and research fellow of the Quality of Government Institute, both at the University of Gothenburg, Sweden. Carl Dahlström (carl.dahlstrom@pol.gu.se) is professor of political science, and research fellow of the Quality of Government Institute, both at the University of Gothenburg, Sweden. Mihály Fazekas (mf436@cam.ac.uk) is a postdoctoral research fellow at the University of Cambridge, United Kingdom, and scientific coordinator at the DIGIWHIST project. Victor Lapuente (victor.lapuente@pol.gu.se) is associate professor of political science and research fellow of the Quality of Government Institute, both at the University of Gothenburg, Sweden.

Funding for this project comes from the Seventh Framework Programme for Research and Development of the European Union, project number 290529. This research project is part of ANTICORRP (http://anticorrp.eu/). Data and supporting materials necessary to reproduce the numerical results in the article are available in the JOP Dataverse (https://dataverse.harvard.edu/dataverse/jop). An online appendix with supplementary material is available at http:// dx.doi.org/10.1086/687209.

The Journal of Politics, volume 79, number 1. Published online October 27, 2016. http://dx.doi.org/10.1086/687209

(c) 2017 by the Southern Political Science Association. All rights reserved. 0022-3816/2017/7901-0007\$10.00 
tives to speak truth to power (Dahlström, Lapuente, and Teorell 2012; Gingerich 2013; Miller and Whitford 2007; Rauch and Evans 2000).

This article makes use of the subnational variation within Europe, where there is an often ignored variation in corruption, prosperity, and health, as well as in cultural and institutional factors. It provides an excellent opportunity for testing comparative theories with new data. We compare 212 European regions using two unique data sets. On the independent side, by measuring career incentives in the public sector we develop a new, more experience-based measure from a recent survey of over 18,000 public sector employees, while we take advantage of a novel objective corruption risk measure on the dependent side, based on over 1.4 million public procurement contracts.

The article makes at least three contributions. First, although there are important exceptions, most studies have focused on political institutions (or on economic and cultural factors) but have left bureaucracy out of the story. While much has been learned about the political constraints needed for good governance, and the economic and cultural conditions often correlated with it, not assigning the bureaucracy any agency in its own right is not only a misrepresentation of reality but comes with an obvious risk of biased results. Second, those studies that have analyzed bureaucratic institutions have, owing to data limitations, mainly worked with aggregated data on the national level, often entirely trusting perception-based measures (Dahlström et al. 2012; Rauch and Evans 2000). The perception-based measures have certainly been important for developing the field, but they have also suffered a great deal of criticism (Andersson and Heywood 2009; Kurtz and Schrank 2007). There is a demand for more experience-based and objective measures of good governance and corruption, and this study provides one such measure on the level of meritocracy and one on corruption risks. Third, prevailing theories of institutional effects are often developed with a handful of countries in mind, and tested on more or less the same set of countries, which violates basic advice in comparative social science design (King, Keohane, and Verba 1994). Our focus on a central aspect of bureaucratic institutions, namely, career perspectives, and a research strategy that explores subnational variations address all these issues.

\section{HOW MERITOCRACY AFFECTS CORRUPTION RISKS}

This article investigates corruption risks on the grand levelmore specifically, the extent to which public positions can be used to benefit particular business interests (Rose-Ackerman 1999, chap. 3). We study public procurement processes and try to assess why some officials favor entrenched contractors, while others assign public contracts more impartially. Our analyses start from the research arguing that unconstrained elites always have incentives to take advantage of their positions and enrich themselves and their clique at the expense of general welfare (Acemoglu and Robinson 2012; Fukuyama 2011; North, Wallis, and Weingast 2009). Those who have the greatest chances for corruption, and whose action might have the most far-reaching consequences, are thus in a constant "moral hazard" (Miller 2000, 289). However, the large variations in corruption levels and welfare provision worldwide suggest that such moral hazards can be handled under the right circumstances.

A promising line of research has noted that the design of bureaucratic staff might help to explain this variation. Patronage-based systems where politicians appoint a large number of public employees at will have been argued to be a "necessary condition for the emergence of ... particularistic exchanges" such as corruption (Kopecký and Scherlis 2008, 357) and other "excesses" (Geddes 1991, 372). Although it has recently been argued that bureaucrats directly responsive to politicians are better at providing public goods (Nath 2015), analyses of very different countries have linked lower levels of corruption and wasteful government spending to higher levels of meritocracy (Dahlström et al. 2012; Kitschelt and Wilkinson 2007; Piattoni 2001; Rauch and Evans 2000).

There are several mechanisms by which a merit-based bureaucracy - as opposed to one where politicians appoint employees at will-is expected to curb corruption. First, merit-based employees may be less prone to corrupt behavior simply because, as argued by Weber ([1922] 1978q), requiring a civil service exam or a university degree produces a more capable pool of officials (Rauch and Evans 2000). A more competent staff is more likely to resist day-to-day political pressures (Olsen 2006).

Second, even if they are not "better types" to start with, bureaucrats improve motivation and performance by socializing and internalizing the norms of good conduct of their esprit de corps, when meritocracy and hard work, rather than connections, are the key to a successful career in the public sector (Rauch and Evans 2000). Unlike political appointees, merit-recruited bureaucrats internalize rules of what represents exemplary behavior (Olsen and March 2008). These shared norms increase "the intangible costs of engaging in deviant behavior like corrupt practices" (Henderson et al. 2007, 517) and "ensure responsible action even when no one is watching" (Jos and Thompkins 2004, 256).

A third mechanism by which a meritocratic bureaucracy constrains particularistic rent-seeking in the public sector is 
by enlarging the time horizon of public employees. A meritocratic bureaucracy is a "dramatic instance of deferred compensation" (Miller 2000, 316) in which public employees are rewarded for making a lifetime commitment to the public administration that, in turn, encourages them to neglect short-sighted and efficiency-undermining political pressures (Gingerich 2013). A longer time horizon makes the quick returns from corrupt deals less attractive (Olsen 2006). In addition, the expectations of long-term careers encourage more competent people to join the public sector and create a virtuous spiral (Henderson et al. 2007).

Fourth and finally, the separation of careers between politicians and bureaucrats gives both types of actors stronger incentives to engage in mutual monitoring, exposing each other's potentially corrupt activities, than would be the case in a public administration filled with political appointees (Dahlström et al. 2012). In the latter, officials share a common interest in keeping the incumbent party in office and thus to turn a blind eye in case they suspect there is corruption. This mechanism echoes an idea according to which countries with two veto players have lower levels of corruption than countries with only one veto player: collusive behavior is more difficult when decision makers have heterogeneous preferences (Andrews and Montinola 2004).

One can find empirical illustrations of these mechanisms linking meritocracy to low corruption both historically and today. In the nineteenth century, British and US reformers advocated separating the careers of politicians and bureaucrats in order to minimize the morally hazardous behavior prevalent in their highly politicized administrations. In Britain the 1854 Northcote-Trevelyan Report promoted a meritocratic administration (Greenaway 2004). And in the United States, contemporary observers like William Clarke noted that "as official patronage, either direct or indirect, is a great if not perhaps the chief cause of corrupt elections, it logically follows that the less patronage there is, the less corruption there will be" (quoted in Frant 1993, 994). Consequently, progressive reformers sponsored civil service mechanisms aimed at protecting the public workforce "from much of the dayto-day political influence that was present in an earlier period" (Miller 2000, 316).

Nowadays, the remarkable variation in corruption across Spanish regions illustrates the connections between meritocracy and corruption. On one side, there is a "tradition" (Buck 2013) of politicians receiving bribes from construction tycoons and private contractors in many Spanish regions, such as Valencia, Murcia, Madrid, and León (Kassam 2014), as well as in Catalonia (Hernández 2015). The modus operandi has been similar across all these regions: firms give a sum - generally around 3\% of the public tender - to politicians who, in turn, persuade civil servants to bend the rules of the public tender offering so as to benefit a certain bidder.

Police and judicial investigations have documented the key role played in these corruption scandals by public employees whose professional careers critically depended on their political superiors. For instance, in Operación Gurtel, where it is estimated that $€ 449 \mathrm{~m}$ were lost in a series of corrupt public procurement contracts, many bureaucrats realized the public contracts could be fraudulent and nevertheless did not expose them (Olaya 2013). Testifying before court, several public employees acknowledged they were told "which contractor must win" and, if they complained, they were "threatened" with dismissal (Gürtel 2014). On some occasions, the public employees were so concerned by the "shoddy quality" of the materials used by the favored contractor that they feared catastrophes could follow as a result of the collapse of the public work; and yet the fear of losing their job was so strong that public employees reported neither to the media nor to judicial authorities (2014).

In sharp contrast to these Spanish regions stands the Basque country, which ranks as Spain's least corrupt region in comparisons of European regions (Charron, Dijkstra, and Lapuente 2015) and tops Transparency International's ranking of Spanish regions. One reason for the Basque country's performance may lie in the administrative reforms undertaken in the region during the latest decades, which have increased meritocracy and professionalism. Indeed, after the Spanish transition to democracy in the late 1970s, the Basque administration was "characterized by its politicization" (Llera 2000 , 35). A pioneering comparative study of politicization of regional administrations showed that the Basque administration was neither significantly more nor less politicized than other Spanish regions (Mesa 2000).

However, the Basque country has adopted a series of institutional changes that have distanced its administration from those of other Spanish regions. Already in 1983 the Basque country created an autonomous institution-the Instituto Vasco de Adminstración Pública (IVAP) - to be in charge of the selection of civil servants, which has over the years contributed to generate a more autonomous bureaucracy (Hernández 2010). The Basque country has adopted more measures devised at limiting at-will appointments at the top of the administrative units, and both the Basque regional administration and the Association of Basque $\mathrm{Mu}$ nicipalities have been forerunners in the adoption of Codes of Ethics that promote impartial conduct and discourage favoritism among their higher civil servants. These initia- 
tives have been linked to the lower levels of corruption observed in the Basque country (Jiménez-Asensio 2013).

All in all, both theoretical accounts and empirical evidence point at an association between the type of staff policy prevalent in the bureaucracy (whether careers are dependent on merit and hard work or on connections) and the levels of corruption. We have highlighted four different mechanisms that could causally link career structures to corruption. As we will describe further in the next section, this article is not designed to discriminate between these different mechanisms but rather to offer a comprehensive empirical test of the relation between meritocracy and corruption, using new and better data, that takes both cross-country and withincountry variation into account.

\section{RESEARCH DESIGN, DATA, AND METHOD}

To the present, most analyses of corruption causes have been national comparisons, and scholars are often forced to work with perception-based measures, such as the well-known "Control of Corruption" index from the World Bank and the "Corruption Perceptions Index" of Transparency International. Although studies using these approaches have indeed contributed extensively to the field, they are limited by both design and data. Cross-national comparisons of causes of corruption have at least two, and sometimes three, problems in common.

First, and perhaps most important, theories tested with cross-national comparisons almost always draw information initially from differences between the same countries. We are certainly not saying that there is something wrong with developing theories inspired by empirical observations; that is only natural, but as forcefully argued by King et al. (1994), making theories less restrictive after empirical observations in one data set requires new data in order for the theory to be properly tested. It otherwise comes close to data fitting, which in turn increases the risk of omitted variable bias.

Second, there are good reasons to believe that withincountry differences are as important as between-country differences. In Italy, for example, the northern regions resemble the best performing German Länder in factors such as unemployment, per capita income, education, and corruption, while the southern regions look more like the lowest performing countries in the European Union. Similarly large differences can be found in Belgium, Spain, Romania, and many other countries (Charron et al. 2015). In a worldwide analysis explaining variation in economic development and productivity, Gennaioli et al. (2011) find that subnational explanatory factors often trump national level factors. Crossnational comparisons miss this variability as they trust the less informative country mean and thus expose themselves to what has been called the "whole nation bias" (Rokkan 1970). Snyder (2001) underscores that, as comparativists are naturally limited by data availability, they need to increase the number of cases as much as possible, and subnational comparison offers a particularly promising avenue for doing so.

Third, studies that use standard indicators of corruption and good governance are also affected by the widely held critique of these measures for being imprecise due to their heavy dependence on perceptions. The standard request is to take individual experiences and objective indicators of corruption into consideration to a greater extent and move away from perceptions (Andersson and Heywood 2009; Kurtz and Schrank 2007).

This article speaks to these problems by analyzing subnational data, with newly collected data for both the dependent and the independent variables. Our data allow us to build a more experience-based measure of the career incentives in the public sector on the independent side and a novel objective corruption risk measure, based on over 1.4 million public procurement contract awards, on the dependent side. The next two sections describe these two data sets in detail.

However, before we discuss the data sets, we would like to address a key issue in any analysis at the subnational level. In countries such as Germany, Belgium, Italy, or Spain, local constituents elect regional governments that are to some degree autonomous in terms of forming their administration while, in more politically centralized countries, such as Bulgaria, Romania, Slovakia, or Portugal, the regions that we use (so-called NUTS-1 and NUTS-2) are meaningful only in the sense that EU development funds are targeted directly to them and that Eurostat reports annual data on them. It can therefore be argued that administrative and political responsibility varies too much. This study argues otherwise, in that we attempt to capture all regional variation within a country. This is defendable, we think, as scholars have noted that the provision and quality of public services controlled by a powerful central government can nonetheless largely vary across different regions (Tabellini 2010). We will take this potential objection to our data into special consideration in our analysis, however, and rerun all models with only the politically meaningful regions - for example, those with a directly elected parliament at the level of analysis in our study - in the sample.

\section{Corruption risks}

On the dependent side, this article uses public procurement data to assess the risk of high-level corruption. It is the first 
time this kind of data is used in an international comparative context. The data contain information on individual public procurement tenders that is regulated administrative procedures in which public bodies purchase goods and services for the 28 EU member states (EU28) between 2009 and 2013, including, for example, contract value, the deadline for submitting bids, and the assessment criteria used. They derive from the European Union's Tenders Electronic Daily (http:// ted.europa.eu/), which is the mandatory online publication that falls under the remit of the Public Procurement Directive that aims to foster a single market in government contracts. This means that large (both national and EU) contracts are included in the database, with publication thresholds varying over time while being approximately 125,000 Euro for service contracts and 4,000,000 Euro for public works contracts. The database contains about 2.2 million contracts awarded for the entire period; however, we used data on only 1,403,939 contracts, excluding small countries without a sufficient number of contracts and dropping contracts below the mandatory publication threshold. As a result, 26 EU member states (EU26) have indicators derived from public procurement microdata. ${ }^{1}$ Similarly structured and regulated public procurement data exist across the globe, making our measurement strategy generally replicable outside Europe as well (http://ocds.open-contracting.org/). The full contract-level public procurement database can be downloaded at digiwhist.eu/resources/data.

Region-level procurement variables are defined by aggregating contracts awarded by local public bodies and agencies, using information on the location of the contracting entity. Corruption risk measurement solely builds on those characteristics of the tendering processes that are in the hands of the local contracting entities within the boundaries of national and regional procurement laws, for example deciding on the deadline for submitting bids (for full indicator description see Fazekas-Kocsis 2015). While investments in a particular region by bodies located in another region may also influence the corruption risk level of that region, we focus only on the local decision-making powers when we define regional corruption risk levels.

We capture high-level corruption risk at the regional level. Our measures tap into a deliberate restriction of open competition for government contracts in order to benefit a well-connected company, and we operationalize our dependent variable in two ways, differing only in the number of components included. To avoid distortion from less com-

1. The data include all EU28 countries except Malta and Croatia. petitive markets such as defense, the indicators are defined only when at least 10 contracts were awarded in 2009-13, indicating a sufficient demand for at least two operating companies. $^{2}$

First, the simplest indication of corruption risks is when only one bid was submitted in a tender on an otherwise competitive market. Hence, the percentage of single-bidder contracts awarded in all the awarded contracts is the most straightforward measure we use.

Second, our complex indicator also incorporates characteristics of the procedure that are in the hands of public officials and suggests deliberate competition restriction. In addition to the percentage of single-bidder contracts awarded, the following process-related indicators of corruption risks were included: (i) A restricted, nonopen tendering procedure such as invitation tenders that are by default much less competitive. Using less open and transparent procedure types can indicate the deliberate limitation of competition, hence corruption risks. (ii) The use of subjective, nonprice related assessment criteria: different types of evaluation criteria are prone to fiddling to different degrees, subjective, hard-toquantify criteria often accompany rigged assessment procedures as they create room for discretion and limit accountability mechanisms. (iii) Very short advertisement period: if the number of days between advertising a tender and the submission deadline is too short to prepare an adequate bid, it can serve corrupt purposes, whereby the issuer informally tells the well-connected company about the opportunity well ahead of time. (iv) A quick evaluation of bids: if the time used for deciding on the bids submitted is excessively short or lengthened by legal challenge, it can also signal corruption risks. Snap decisions may reflect premeditated assessment, while legal challenge and the corresponding long decision period suggest an outright violation of laws. Each of these are large and significant predictors of single-bidder contract awards when controlling for the sector of the contracting entity (e.g., education, health), type of contracting entity

2. In the absence of company identifiers in the EU-wide public procurement data set, we derived the cutoff of contract number by analyzing the United Kingdom subsample where we manually assigned company IDs by matching names and addresses to registry records. Cross-tabulating number of contracts awarded on the market and the number of different companies supplying the UK government shows that the number of markets with less than two companies drops below 5\% among markets with at least 11 contracts awarded, with the average number of companies steadily increasing as the number of contracts increase. Hence taking 10 contracts per market is a conservative cut-point for identifying competitive markets with multiple potential suppliers. 
(e.g., municipality, central government), year of contract award, main product market of procured goods and services (e.g., roads, training) and contract value. The average unweighted incidence of single bids received and the four processes related to "red flags" constitute a composite indicator: the corruption risk index $(0 \leq \mathrm{CRI} \leq 1$, where $0=$ minimum corruption risk and $1=$ maximum corruption risk). ${ }^{3}$

While the validity of both outcome measures predominantly stems from their fit with the definition of high-level corruption, their association with widely used survey-based corruption indicators and further objective indicators of corruption risks underpins their validity. As reported in table 1, both corruption risk indicators (2009-13 averages per NUTS region) correlate as expected with the European Quality of Government Index (EQI), which to our knowledge is the best regional measurement of institutional quality and corruption, and to two subcomponents of the EQI, corruption perceptions of public sector services and reported public sector bribery.

To further explore the validity of our measure, we also inspect two more objective micro-level risk indicators, namely the procurement suppliers' country of origin and contract prices. First, it is expected that higher corruption risk contracts are won by companies registered in tax havens as their secrecy allows for hiding illicit money flows (Shaxson and Christensen 2014), which is shown in the case in figure 1. Second, we expect corruption to drive prices up. A simplistic, albeit widely used, indicator of price in the absence of reliable unit prices is the ratio of actual contract value to initially estimated contract value (Coviello-Mariniello 2014). As expected, both the single-bidder contract and CRI are associated with a higher price ratio. Single-bidder contracts are associated with a $7 \%$ higher contract value, while contracts with 1 CRI higher are associated with a $9 \%$ higher contract value, both reported in table 2 .

All in all, the validity checks strengthen our confidence that both our measures are indeed picking up high-level corruption risks.

\section{Meritocratic career incentives in the public sector}

The data on meritocracy in the public sector in this study are taken from the largest multi-country survey that specifically focuses on matters of governance and corruption-with a

3. We find that regional variation within countries is quite significant. Running empty hierarchical models (constant only) with random country effects yield an interclass correlation of 0.70 and 0.65 for the single bidder and combined index respectively, meaning that accounting for countrylevel variation alone would overlook $30 \%$ and $35 \%$ of the total variation in corruption risk in the sample ( $p<.000$ in both cases).
Table 1. Bivariate Pearson Correlation between "Objective" Measures of Regional Corruption and Survey-Based Indicators

\begin{tabular}{lccc}
\hline Variable & $\begin{array}{c}\text { Percent } \\
\text { Single Bidder }\end{array}$ & $\begin{array}{c}\text { Regional } \\
\text { CRI }\end{array}$ & Observations \\
\hline $\begin{array}{l}\text { Percent single } \\
\quad \text { bidder }\end{array}$ & & & \\
Regional CRI & $.69^{*}$ & $.69^{*}$ & 185 \\
EQI (2013) & $-.61^{*}$ & $-.54^{*}$ & 185 \\
Corruption & & & 185 \\
$\quad$ perception & $.55^{*}$ & $.47^{*}$ & 185 \\
Reported bribery & $.53^{*}$ & $.59^{*}$ & 185 \\
\hline
\end{tabular}

Note. CRI = corruption risk index; EQI = European Quality of Government Index.

${ }^{*} p<.05$.

total sample of over 85,000 randomly selected respondents 18 years or older via the next birthday method in 24 European countries using computer-assisted telephone interviewing (CATI) to ensure uniformity. The survey is especially suited for this analysis due to its regional focus (400-450 randomly selected respondents per region) and was mainly concerned with European citizens' perceptions and experiences on the corruption, quality, and impartiality of regional public service; the survey was conducted between February and April 2013 by the authors in collaboration with the EU Commission. The respondents were asked all questions in the majority language of their region or country and were interviewed via telephone with a mix of landline and mobile contacts, and the sampling frame was households (for landlines) and individuals (for mobile phones). The response rate was roughly $21 \%$, a rate consistent with, or higher than, many other large telephone-administered surveys (Pew Research Center 2012). ${ }^{4}$ More details about the survey are given in the appendix, available online, and in Charron, Dahlström, and Lapuente (2016).

Measuring such independence directly is obviously a challenge, and (like those before us) our measure is indirect. However, on the continuum between perceptions and experienced-based measures, ours certainly leans more toward the latter, which is an improvement over measures based solely on perceptions or the opinions of outside experts. We include only individuals with a direct experience

4. While $21 \%$ might seem rather low, several recent studies have shown that high response rates may in fact be overrated relative to the costs in obtaining them-e.g., Pew Research Center (2012) shows that results from groups of respondents and nonrespondents produces very similar findings. 


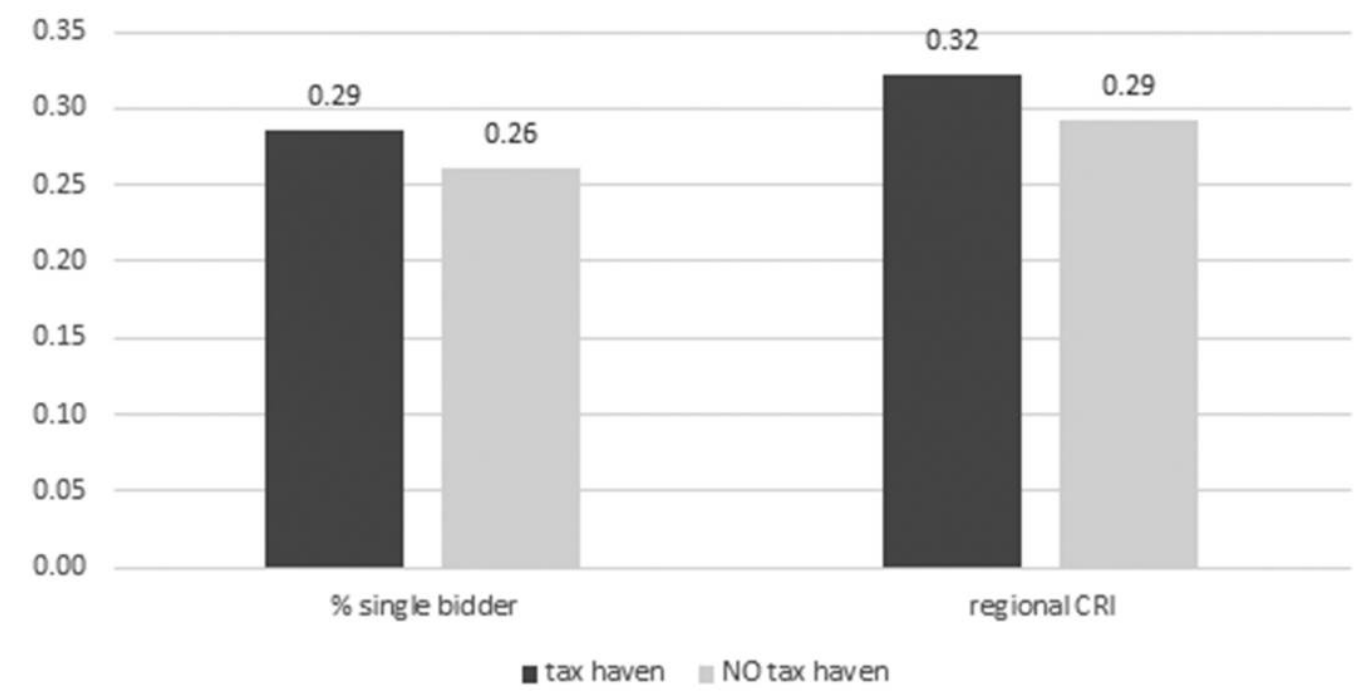

Figure 1. Average corruption risks of public procurement suppliers registered abroad, EU26, 2009-2013, $N_{\text {contract }}=14,909$.

of what they are answering; thus, we first record if a respondent answered that they were employed in the public sector. In total, 18,335 respondents reportedly worked in the public sector in some capacity. We then use a 10-scale question asking what the respondent thinks is closest to her own view: "in the public sector, most people can succeed if they are willing to work hard" (1) or "hard work is no guarantee of success in the public sector for most people-it's more a matter of luck and connections" (10). (See Charron et al. [2016] for a more detailed discussion about the measure.)

Finally, we aggregate the scores by NUTS-1 and NUTS-2 region in each country, taking each region's mean score and its standard error. Overall, we find that there is significant variation in how public sector employees view the road to success in their field, although respondents in the majority of European regions tend to lean toward "luck and connections" (as indicated by a score greater than $5^{\prime}$ ). We reverse the scores and find that the regional scores range from least meritocratic, 1.7 (Belgrade Region, Serbia) and 2.1 in the relevant sample (Severozapaden, Bulgaria), to most, 5.6 (Southwest England). Figure 2 shows the distribution by region in the sample. Regions that are shaded lighter are considered more meritocratic. We produce a $95 \%$ confidence interval for each region's point estimate to show statistical significance from one region's estimate to another.

Cross-country measures of public sector meritocracy are scarce, especially at the regional level, and thus finding data to assess external validity is somewhat of a challenge. However, cross-national measures of public sector impartiality and professionalism, which is similar to our concept, are available for all of the countries in our sample. These data are based on expert survey data from the Quality of Government
Institute (Teorell, Dahlström, and Dahlberg 2011). In aggregating our regional measure to the country level, we obtain Spearman rank correlations of $0.76(p=.000)$ and 0.80 $(p=.000)$ between our measure and the expert survey measures of impartiality and professionalism, respectively, showing a strong degree of consistency between the two sources.

\section{Estimation techniques}

Due to the nature of the data, a concern is our unit of analysis (regions in countries). We ran a White-Koenker test of heteroskadascitiy from bivariate corruption-career models. These show signs of heteroskadasticity due to country clustering $(p=.02)$, while in later models with more control variables, the test shows stronger signs $(p<.01)$. This issue leads to a second potential violation of OLS - that our observations might not be independent due to the regions

Table 2. Linear Regression with Relative Contract Value, EU26, 2009-13

Independent Variable (1)

Percent single bidder

Regional CRI

$N$

$R^{2}$

$.071(.000)$

164,711

.088

$.090(.000)$

164,711

.086

Note. Each regression controls the sector of the contracting entity, type of contracting entity, year of contract award, country of contract award, main product market of procured goods and services, and contract value. $\mathrm{CRI}=$ corruption risk index. 


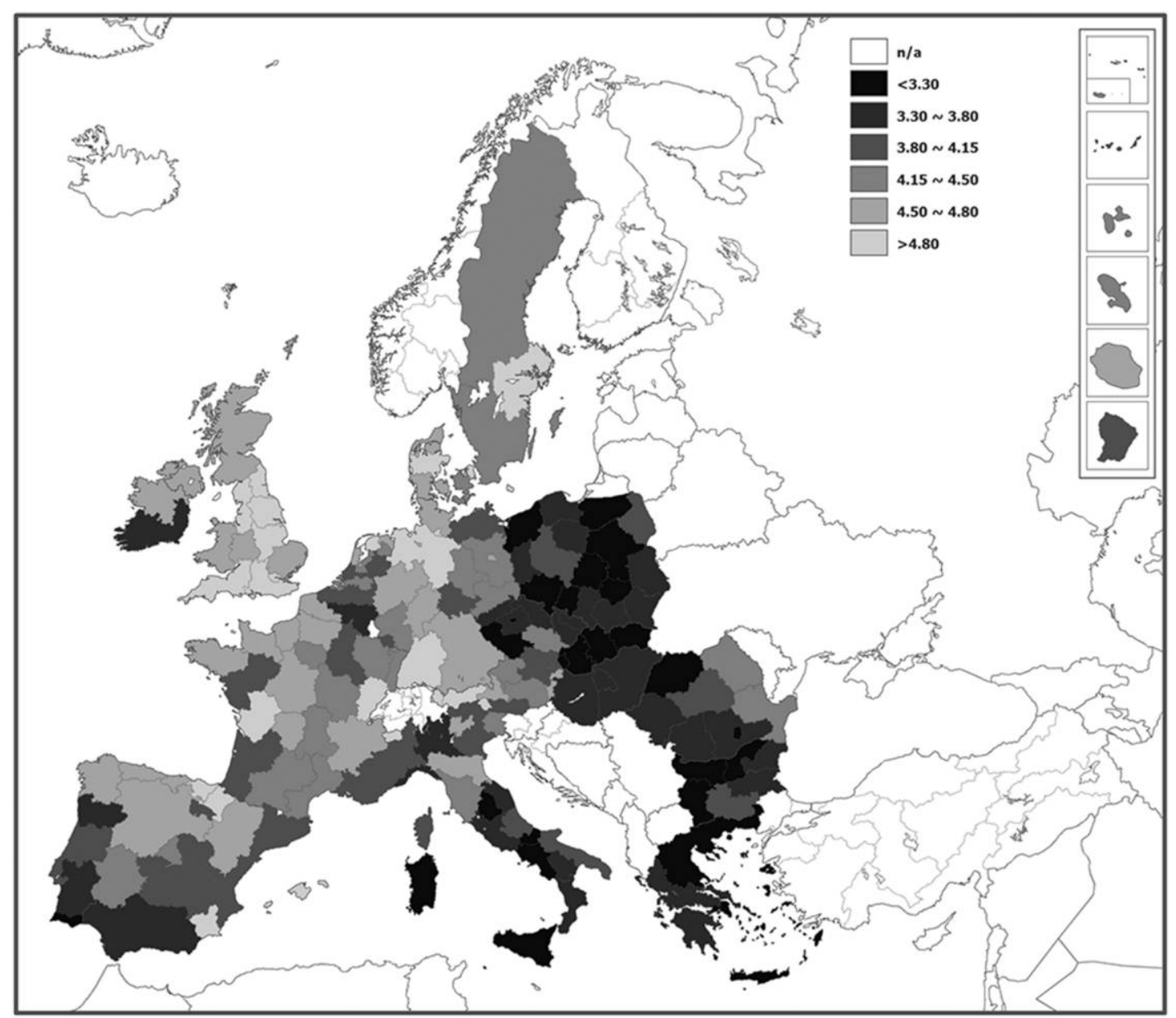

Figure 2. Career incentives for working hard in the public sector by European region. Scores have been reversed so that higher values equal greater merit. Lighter shades indicate more independence of careers.

being nested in countries. This implies that there are spatial dependencies in the data and that the slope estimates; in particular, the standard error can be biased due to issues of group-wise heteroskadasticity. There is ongoing debate as to how to model this issue, where several possibilities can be considered (Bryan and Jenkins 2016; Goldstein 2011; Huang 2016): first, clustered standard errors in normal or weighted regression; 5 second, fixed effects models, which isolate the variation of the variables within countries; third, random effects hierarchical models, which allow for random country intercepts. On the basis of this and the nature of our data, we take the country context into account via clustered (country)

5. We experiment with two weights. First, since our regions are of varying sizes, with some large (Catalonia, Bavaria, etc.) and some small (Bolzano, Azures), we weight each region by its relative population sample, giving more weight to regions with larger populations. Second, we rerun models using the inverse of the standard error of the estimates of meritocracy by region. Third, we rerun models without weights. standard errors and run models with hierarchical estimation (regions nested in countries). In addition, we also model directly the spatial dependence across units with several autoregressive models, accounting for corruption risk levels in neighboring regions (Haining 2003). Essentially, we add an extra parameter to these models, which is a distance-weighted function of the average neighboring corruption risk. ${ }^{6}$

Moreover, as the data are cross-sectional, we run an obvious risk of endogenity between the two main variables. To

6. Formally, our autoregressive measure " $A$ " is constructed as:

$$
A_{i}=\frac{\sum_{j \in n_{i} w_{i j} Y_{j}}}{n_{i}}
$$

where $Y_{j}$ is the value of corruption risk for $i$ 's set of " $n_{i}$ " neighbors, and $w_{i j}$ is the weight given (in our case " 1 " for contiguous neighbor, "0" if otherwise). We construct two measures using this formula, one that capture all contiguous neighbors and one for only neighbors within region i's country. 
deal with this issue, we also employ a two-stage least-squares (2SLS) instrumental analysis in several models. While instruments are admittedly difficult to find, we explore two possibilities.

First are the literacy rates in 1880, which we argue would be a determinant of the meritocracy in the bureaucracy today. Hollyer (2011) argues that introducing civil service reforms that separated bureaucratic and political careers was only introduced when there was a pool of qualified candidates. A country or region with lower literacy rates is thus expected to have stronger incentives for rulers to introduce meritocracy. Some readers might be skeptical of this instrument in that it determines corruption risk and hence would be correlated with the unobserved variance. We argue, however, that greater past literacy rates should not be directly correlated with current corruption risk levels but that this relationship works through other channels, such as improved bureaucratic independence (our hypothesis) or through a conditional relationship, such as a free press. Theoretically, there is nothing inherently benevolent about low literacy rates, which could also increase the opportunity for more people to cheat the system via forgery, for example. Moreover, cross-country data show that, while the least corrupted countries in the world all have had near universal literacy for decades, other countries considered highly corrupt, such as post-Soviet Russia, the Ukraine, Uzbekistan, Azerbaijan, Turkmenistan, and Kyrgyzstan have, for the entire postwar era, also been some of the most highly literate places in the world. In Africa, according to some of the latest data on literacy and corruption, two of the most corrupt countriesEquatorial Guinea and Zimbabwe-are also the most literate. ${ }^{7}$ Thus, at best there is an indirect relationship between aggregate literacy and corruption, rendering this instrument theoretically valid. ${ }^{8}$ In addition, past literacy rates have also been used in previous empirical studies as an instrument for

7. Using 2013 corruption data from Transparency International's Corruption Perception Index, the two countries rank in the bottom 5\% in the world, while the latest CIA World Factbook data note that Equatorial Guinea and Zimbabwe have literacy rates of $95.3 \%$ and $90.5 \%$, respectively, the two highest on the continent.

8. In addition to our hypothesis, it is possible that literacy rates have a conditional effect on corruption risk based on factors such as press freedom levels or democracy. The cross-national data cited here on literacy and corruption risk suggest that, in the absence of either press freedom or democracy, it is unlikely that literacy rates will have an effect on either corruption risk or even meritocracy as it is conceived here. Our model implies that, in democratic states with press freedom, the effect of literacy on corruption risks channels through meritocracy in the bureaucracy. As space is limited in this analysis, we leave more direct tests of these possible interactions to future research. testing cultural or institutional development (Charron and Lapuente 2013; Tabellini 2010). However, it should be noted that a debate exists in the literature regarding how past education levels affect current day corruption, with some arguing the effect is more direct through other channels, such as economic equality, which we control for (Uslaner and Rothstein 2016).

Second, building on Weber ([1904] 2002), we use the proportion of Protestant residents in a region as an instrument for a more developed bureaucracy. Protestantism implies a state church, which deprives the ruler the possibility to use an outside organization, such as the Catholic church, for provision of, for example, education and census, and in turn increases incentives for early investments in a merit bureaucracy. Evidence shows that, historically, counties in Germany with higher concentrations of Protestantism have had better education and human capital development (Becker and Woessmann 2009). In addition, Tabellini (2010) uses Protestantism in a sample of European regions as an instrument to explain beneficial aspects of modern day culture, which in turn lead to greater levels of economic development.

In many cases, we have regional estimates for both literacy rates and Protestantism. However, where we could not find statistics at the regional level, we employ country averages. In addition, if we were able to control for corruption at the time of our instrumental variables, then we would significantly increase the validity of the instruments. Yet corruption data do not go back this far, and we thus use the data available, and this missing aspect is a shortfall in the estimation. We provide several tests of instrumental validity in these models. More detail on the two instrumental variables is given in appendix C. ${ }^{9}$

\section{ALTERNATIVE EXPLANATIONS}

Although the main purpose of this article is to study implications of the suggestion made above, we also take into account explanations from comparative studies of control of corruption that are reasonable at the regional level.

First, we follow authors who regard economic development as a prerequisite for good government and low corruption. Different versions of this argument can be found in the work of Boix and Stokes (2003), Lipset (1960), or Welzel and Inglehart (2008). We control for the overall level of eco-

9. We test whether the instrumental variables meet the exclusion restriction for valid instruments by including them in the main regression model (model 8 in table 3 ), and we find neither to be significant when including meritocracy. 
nomic development and for the rates of growth in the last years in order to capture both the level and recent trends in regional economic development. We take the purchasing power per capita for the most recent year (2012) and the year 2000 (the year furthest back that is available) from Eurostat. The growth rates are taken over this period.

Second, we follow a large body of literature on trust and good government that has found how low-corruption countries (Rothstein and Uslaner 2005; Zack and Knack 2001) and low-corruption regions (Putnam 1993; Tabellini 2010) tend to have populations with high levels of social capital. We take the average degree of generalized trust into account from a recent study by Charron and Rothstein (2014). The level of civic participation is captured via rates of electoral turnout for the latest regional level election (where applicable).

Third, since the accumulation of political power has been noted as being important for understanding corruption (Andrews and Montinola 2004), we control for five variables used in previous regional studies of corruption (Charron and Lapuente 2013): (i) the fractionalization of a region's parliament, (ii) the proportion of years a region has been governed by a single party, (iii) whether the region has a minority government, (iv) how long the current party or coalition has been in power, and (v) the electoral threshold that acts as an entry barrier for new political competitors at the regional level.

Fourth, although the causal relationship is debated, countries with higher levels of income/wealth inequality tend on average to have higher corruption (Jong-sung and Khagram 2005). We use a Theil index of inequality of wages in six sectors of employment with the latest regional data (2010) from Galbraith and Garcilazo (2005) and the percentage of residents at risk for poverty by region in 2012 (Eurostat).

Fifth, several studies have looked at gender inequalities and corruption levels and found strong correlations among these two factors (Wängnerud 2009), pointing out that greater levels of participation of women equate with lower levels of corruption (Swamy et al. 2001). We control for the percentage of women in a region's parliament taking data from Sundström (2013).

Sixth, and finally, we control for a geopolitical factorwhether the region is the country's capital-and demographic factors - such as the region's population and population density, taken from Eurostat.

In some cases (data from ESS, women in parliament, Theil measure of wage inequality), the NUTS regions provided did not correspond to those in our data for all countries. In all cases, the NUTS regions from other sources were lower (smaller regions); thus, we aggregated from NUTS-2 to NUT-1 or NUTS-3 to NUTS-2 using regional population weights taken from Eurostat.

\section{RESULTS}

We begin by looking at the bivariate relationship between meritocracy in the public sector and corruption, which is relatively strong. The bivariate correlations with our measures of the dependent variables are significantly correlated in the expected direction with career independence $(p \leq .000)$. We provide scatterplots in appendix B showing that, on average, regions with greater meritocracy are associated with lower corruption.

We include control variables, reported in table 3, one at a time, and then finish with two full models (models 8 and 9). The "percent single bidder" is used in all models as the dependent variable, whereas our other measure (CRI) is found together with a third measure for robustness (percentage of self-reported bribery by region) in appendix B.

The level of meritocracy is a strong predictor of corruption risks in European regions, irrespective of the estimation method or control variables. A one-unit increase in meritocracy decreases corruption risk by between - 09 (model 8) and -.14 (model 1). The effect is significant above the $99 \%$ confidence level in all models. See table 4 for a more concrete interpretation, which elucidates the marginal effects of meritocracy on corruption from the most conservative estimate (model 8). We highlight predicted levels of corruption at the minimum value, 25 th percentile, mean, 75 th percentile, and max levels of meritocracy, along with standard errors and confidence intervals. The model indicates that the lowest levels of corruption differ significantly from mean values and above. The 75th percentile is distinguishable from both the mean and high values.

A min-max change in career independence is associated with a decrease in 17 times fewer single-bid procurement contracts in a region ( 0.34 to 0.02 ), while moving from the 25 th to 75 th percentile reduces single bids by almost half. This is reported in table 4 . There are many examples of such a difference in the sample. Compare, for example, meritocracy between the German states of Thuringia (3.84) and Hamburg (5.17), the former having more than twice the corruption risk of the latter (0.11 to 0.05$)$, or in Spain, the difference between Andalucía (3.72) and Navarre (4.96), which shows a difference in the percent of single bidders of 0.14 ( 0.18 to 0.04$)$.

It is possible to translate these regression results into estimated savings for governments. Moving all regions to the 90th percentile of meritocracy which are below this threshold, that is, making them similar to Yorkshire-Humber or 
Table 3. The Effect of Meritocracy in the Public Sector on Corruption

\begin{tabular}{|c|c|c|c|c|c|c|c|c|c|}
\hline Variable & 1 & 2 & 3 & 4 & 5 & 6 & 7 & 8 & 9 \\
\hline Meritocracy & $\begin{array}{c}-.14^{\star *} \\
(.02)\end{array}$ & $\begin{array}{c}-.12^{\star *} \\
(.02)\end{array}$ & $\begin{array}{c}-.11^{\star *} \\
(.02)\end{array}$ & $\begin{array}{c}-.13^{\star *} \\
(.02)\end{array}$ & $\begin{array}{c}-.10^{\star *} \\
(.02)\end{array}$ & $\begin{array}{c}-.12^{* *} \\
(.02)\end{array}$ & $\begin{array}{c}-.12^{\star *} \\
(.02)\end{array}$ & $\begin{array}{c}-.09^{* *} \\
(.02)\end{array}$ & $\begin{array}{c}-.10^{* *} \\
(.02)\end{array}$ \\
\hline Pop. density (log) & $\begin{array}{c}-.001 \\
(.005)\end{array}$ & & & & & & & $\begin{array}{c}-.002 \\
(.004)\end{array}$ & \\
\hline Capital region & $\begin{array}{c}-.04 \\
(.02)\end{array}$ & & & & & & & $\begin{array}{c}-.001 \\
(.04)\end{array}$ & \\
\hline PPP 2011 (log) & & $\begin{array}{r}-.06^{*} \\
(.03)\end{array}$ & & & & & & $\begin{array}{r}-.03 \\
(.04)\end{array}$ & $\begin{array}{c}-.06 \\
(.04)\end{array}$ \\
\hline PPP 2000 (log) & & & $\begin{array}{r}-.05^{*} \\
(.02)\end{array}$ & & & & & & \\
\hline PPP growth (2000-2011) & & & & $\begin{array}{l}.0003 \\
(.0003)\end{array}$ & & & & & \\
\hline Percent non-EU born & & & & & $\begin{array}{c}-.003^{* *} \\
(.001)\end{array}$ & & & $\begin{array}{c}-.001 \\
(.001)\end{array}$ & \\
\hline Social trust & & & & & $\begin{array}{c}-.14 \\
(.08)\end{array}$ & & & $\begin{array}{r}-.17^{\star} \\
(.07)\end{array}$ & $\begin{array}{c}-.02 \\
(.11)\end{array}$ \\
\hline Wage ineq. (Theil) & & & & & & $\begin{array}{l}-.73 \\
(1.39)\end{array}$ & & $\begin{array}{c}.58 \\
(1.11)\end{array}$ & \\
\hline Percent women parliament & & & & & & $\begin{array}{c}-.02^{\star} \\
(.001)\end{array}$ & & $\begin{array}{r}-.002^{\star} \\
(.001)\end{array}$ & $\begin{array}{c}-.004 \\
(.007)\end{array}$ \\
\hline Party fractionalization & & & & & & & $\begin{array}{c}.03 \\
(.12)\end{array}$ & & $\begin{array}{c}.02 \\
(.11)\end{array}$ \\
\hline Voter turnout & & & & & & & $\begin{array}{c}-.002 \\
(.001)\end{array}$ & & $\begin{array}{c}-.001 \\
(.01)\end{array}$ \\
\hline Constant & $\begin{array}{l}.74^{* *} \\
(.08)\end{array}$ & $\begin{array}{l}1.29^{* *} \\
(.27)\end{array}$ & $\begin{array}{l}1.11^{* *} \\
(.22\end{array}$ & $\begin{array}{l}.68^{* *} \\
(.08)\end{array}$ & $\begin{array}{l}.68^{* *} \\
(.06)\end{array}$ & $\begin{array}{l}.73^{* *} \\
(.07)\end{array}$ & $\begin{array}{l}.72^{* *} \\
(.15)\end{array}$ & $\begin{array}{r}.96^{*} \\
(.36)\end{array}$ & $\begin{array}{l}1.23^{*} \\
(.48)\end{array}$ \\
\hline No observations & 185 & 185 & 185 & 185 & 181 & 182 & 127 & 180 & 122 \\
\hline Countries & 20 & 20 & 20 & 20 & 20 & 20 & 10 & 20 & 10 \\
\hline$R^{2}$ & .50 & .52 & .52 & .49 & .55 & .51 & .44 & .57 & .46 \\
\hline Mean VIF & 1.05 & 1.22 & 1.33 & 1.26 & 1.29 & 1.20 & 1.29 & 2.03 & 2.05 \\
\hline
\end{tabular}

Note. Dependent variable is the percent of single bidders. WLS estimation with robust cluster (country) standard errors in parentheses. Observations are weighted by population. VIF is the mean variance inflation factor, which displays the extent to which multicollinearity might affect the efficiency of a given model. Models 7 and 9 are run with "politically relevant" regions only, hence the drop in observations. PPP $=$ purchasing power parity; VIF = variance inflation factor; WLS $=$ weighted least squares.

${ }^{*} p<.05$.

$* * p<.01$.

Baden-Wüttemberg, would decrease procurement costs by roughly $0.5 \%-0.8 \%$ across Europe: that is, a $13-20$ billion EUR savings per year for the whole European Union in 2010 prices (meritocracy effects derive from models 1 and 8 in table 3, price effect from model 1 in table 2).

Regarding the control variables in table 3 , we find that greater levels of recent and past levels of economic development (purchasing power parity $[\mathrm{PPP}]$ per capita) are significant predictors of less regional-level corruption, but, while recent growth levels are in the expected direction, their effects are not distinguishable from zero in model 4 . We find that greater levels of non-EU born residents are associated with less corruption in model 5 , yet this effect falls below acceptable significance levels in model 8. Regions with higher levels of social trust also tend to have less risk for corruption on average, and the effect is significant at the $95 \%$ confidence interval in model 8. Another strong predictor of corruption levels is gender equality in terms of the percentage of women in the subnational parliament - we find that, for each percent increase, the risk of corruption decreases by $2 \%$ (model 6), and while the effect remains significant, it decreases by 10 -fold in the full model 8 . Other factors such 
Table 4. Marginal Effect of Careers on Corruption as Measured by Single Bidding-from Full Model with Controls

\begin{tabular}{lcccc}
\hline Meritocracy & $\begin{array}{c}\text { Predicted } \\
\text { Corruption }\end{array}$ & $\begin{array}{c}\text { Standard } \\
\text { Error }\end{array}$ & \multicolumn{2}{c}{$95 \%$ CI } \\
\hline Min & & & & \\
25th percentile & .34 & .05 & .24 & .43 \\
Mean & .21 & .02 & .17 & .25 \\
75th percentile & .17 & .01 & .14 & .19 \\
Max & .12 & .01 & .10 & .13 \\
& .02 & .01 & -.03 & .08 \\
\hline
\end{tabular}

Note. Marginal effects calculations from post-estimation command margins in STATA. Estimates from model 8 (full model) are found in this table. Predicted corruption is the proportion of predicted single bidders. $\mathrm{CI}=$ confidence interval.

as wage inequality, population density, capital region, voter turnout, or party fractionalization do not demonstrate significant effects on corruption when meritocracy is accounted for.

For robustness and model checks, the effects are also consistent irrespective of the measure of corruption used (see app. B for results for the CRI and bribery measures). Whether including all regions or only politically relevant ones also plays no role in our main findings. As several of the explanatory variables correlate between 0.4 and 0.5 with our meritocracy measure (in particular, PPP per capita and social trust), we include the variance inflation factor (VIF) for every model to show the extent to which multicollinearity might have an impact on the efficiency of the estimates. In none of the cases do we observe a serious problem. Finally, all models in table 3 are rerun using the multilevel modeling (MLM) estimation, and the full model is rerun removing all outlier regions. ${ }^{10}$ No significant differences are observed in the results.

To address the potential issues of endogenity, table 5 reports models using a 2 SLS specification. The first three models in table 5 are weighted least squares (WLS) regressions with country clustered standard errors and no controls, and they highlight the relationship between the instrumental variables - past literacy rates and proportion of Protestantism - with meritocracy in the public sector. Both are in the expected direction; they are significant at the $99 \%$ level of confidence and remain significant when included together in model 3.

Models 4 and 5 try to isolate the exogenous effects of meritocracy on corruption risks with the use of a 2SLS IV

10. Regions having greater than $4 / \mathrm{n}$ on the Cook's $D$ statistic are defined as outliers. We identify 10 outlying regions and rerun the models without them. The regions are GR2, IE02, ITE2, ITF2, PL62, RO32, FR10, PT15, PT30, and SK01. regression for both our measures of corruption. These models also include control variables (not shown). We find that the effects of meritocracy on both procurement and bribery are remarkably robust to this estimation. Thus we alleviate some concerns that meritocracy in the public sector is endogenous to corruption, that both proxy for a salient omitted variable, and even that our indicators are measured with a sufficiently damaging level of error.

However, this conclusion is only correct if instruments are valid. For an instrument to be valid, it must be correlated with the endogenous variable (meritocracy), but not with the error term in the second stage estimations for corruption when the other regressors are controlled for in the model. The first-stage $F$ test in models 4 and 5 shows that the instruments are strongly relevant (the rule of thumb is an $F$ statistic $>10$ ). The Kleibergen-Paap test shows that our model is not underidentified, while the Hanson's J-statistic, which tests the correlation between the instruments and the second stage error term, shows that the instruments are statistically valid.

Thus far, we have accounted for several factors associated with corruption on a regional level, but some factors from the literature are difficult to disaggregate from the country level with existing data. For example, Brunetti and Weder (2003) point to the level of press freedom being negatively associated with corruption, while Keefer (2007) highlights the effects of the age of a country's democratic institutions as affecting the level of corruption, and much debate has centered around the effects of ethnic diversity and corruption (Alesina et al. 2003). Table 6 therefore focuses on the factors that were not accounted for in the regional level analysis, such as age of democracy, freedom of the press, and ethnic heterogeneity (data from Teorell et al. 2013).

All models include controls at the regional level, and each country level factor is taken one at a time, building up to the full model in models 7 and 8 . The findings here corroborate several previous studies - regions in countries with a longer history of democracy and higher levels of press freedom tend, on average, to have lower corruption, while states that are more ethnically diverse tend to have regions with higher levels of corruption. In none of these models does the impact of career independence on corruption fall from significance, demonstrating strong and robust evidence for our hypothesis. There is also little residual variance of the dependent variable at the country level relative to the regional level, in particular when the three country level factors are included, again highlighting the relevance of the regional level of analysis, which supports using the region as the primary unit of analysis. Finally, we find the results robust to our other measure of corruption (app. B), as well as when we model directly 
Table 5. IV Regression Estimates (2SLS) for Two Measures of Corruption Risks

\begin{tabular}{|c|c|c|c|c|c|}
\hline & \multicolumn{2}{|c|}{ DV, Meritocracy } & \multirow[b]{2}{*}{3} & \multicolumn{2}{|c|}{ DV, Corruption } \\
\hline & 1 & 2 & & Single Bids & CRI \\
\hline Meritocracy & & & & $\begin{array}{c}-.15^{\star *} \\
(.03)\end{array}$ & $\begin{array}{c}-.05^{\star *} \\
(.02)\end{array}$ \\
\hline Past literacy & $\begin{array}{l}.01^{\star *} \\
(.002)\end{array}$ & & $\begin{array}{c}.01^{\star *} \\
(.002)\end{array}$ & & \\
\hline Protestantism & & $\begin{array}{l}2.60^{* *} \\
(.57)\end{array}$ & $\begin{array}{l}1.86^{* *} \\
(.64)\end{array}$ & & \\
\hline Constant & $\begin{array}{l}3.41^{* *} \\
(.15)\end{array}$ & $\begin{array}{l}3.87^{* *} \\
(.14)\end{array}$ & $\begin{array}{l}3.54^{\star *} \\
(.14)\end{array}$ & & \\
\hline $\begin{array}{l}\text { No. obs. } \\
\text { Countries: }\end{array}$ & 183 & 185 & 179 & 175 & 175 \\
\hline$R^{2}$ & .31 & .35 & .43 & .55 & .54 \\
\hline Uncentered $R^{2}$ & & & & .88 & .97 \\
\hline 1st stage $F$ test & & & & $23.2^{\star \star}$ & $23.2^{\star *}$ \\
\hline Kleibergen-Paap $\left(\chi^{2}\right)$ & & & & $18.3^{* *}$ & $18.3^{* *}$ \\
\hline Hanson $J$ test $\left(\chi^{2}\right)(p$-value $)$ & & & & .73 & .28 \\
\hline
\end{tabular}

Note. In models 1-3, OLS with country clustered standard errors (in parentheses). The dependent variable is meritocracy. Models 4 and 5 use the two measures of corruption as the dependent variable and include population density (log), PPP per capita $(2011, \log )$, social trust, percent of women in parliament and robust standard errors in parentheses. In models 4 and 5 , meritocracy is modeled as the endogenous regressor with literacy and Protestantism as exogenous instruments. Regions weighted by population. Relevance of the instruments with meritocracy is tested with the first-stage $F$ test (Ho: instruments are weakly identified). The Kleibergen-Paap $\left(\chi^{2}\right)$ test tests whether the equation is properly identified (Ho: model is underidentified). The Hanson $J$ statistic tests whether the instruments are valid, e.g., uncorrelated with the error term in the second stage (Ho: instruments are valid, $p$-values reported). CRI $=$ corruption risk index; DV $=$ dependent variable; OLS $=$ ordinary least squares; PPP $=$ purchasing power parity.

${ }^{*} p<.05$.

${ }^{* *} p<.01$.

spatial dependencies of the dependent variable (table D4, available online).

\section{CONCLUSIONS}

This article explores corruption risks in public procurement processes across Europe. We document a large variation in corruption risks among 212 European regions using a novel objective measure, based on the analysis of over 1.4. million procurement contracts. The measure avoids the problems of the perception-based measures of corruption generally employed in the literature. In addition, we have linked this variation to the extent to which bureaucrats' careers in the region depend on merits and hard work or, in contrast, on the bureaucrats' political connections, using a pioneering measure of meritocracy based on the self-reported experience with meritocracy of over 18,000 public sector employees. The study reported here is probably the most comprehensive test of the often suggested positive effects of a meritocratic bureaucracy.
Previous studies that test the relationship between meritocracy in the public sector have either been case studies or pure theoretical work, or have employed experts' views of meritocracy and perception-based measures of corruption (Miller 2000; Rauch and Evans 2000).

The empirical analysis given in this article has indeed shown that, controlling for the usual confounders suggested in the corruption literature, making bureaucrats less reliant on political connections reduces the risks of corruption. We have also tried to isolate the exogenous effects of merit and hard work on corruption risks with the help of two instrument variables (past literacy rates and Protestantism), and our indicators show remarkably robust effects. Conversely, where bureaucrats' career incentives exclusively follow professional criteria, we find the lowest levels of risk of corruption.

These findings have several implications. First, reformers' proposals against corruption tend to be aimed at increasing 
Table 6. Effect of Career Independence on Corruption Accounting for Country Level Factors

\begin{tabular}{|c|c|c|c|c|c|c|c|c|}
\hline Variable & 1 & 2 & 3 & 4 & 5 & 6 & 7 & 8 \\
\hline Meritocracy & $\begin{array}{l}-.06^{* *} \\
(.02)\end{array}$ & $\begin{array}{c}-.06^{\star *} \\
(.02)\end{array}$ & $\begin{array}{l}-.09^{* *} \\
(.02)\end{array}$ & $\begin{array}{l}-.09^{\star *} \\
(.02)\end{array}$ & $\begin{array}{l}-.07^{* *} \\
(.02)\end{array}$ & $\begin{array}{l}-.07^{\star *} \\
(.02)\end{array}$ & $\begin{array}{r}-.05^{\star} \\
(.01)\end{array}$ & $\begin{array}{r}-.05^{*} \\
(.01)\end{array}$ \\
\hline \multicolumn{9}{|l|}{$\begin{array}{r}\text { Country level } \\
\text { variables: }\end{array}$} \\
\hline Years of democracy & $\begin{array}{r}-.002^{\star *} \\
(.0004)\end{array}$ & $\begin{array}{r}-.002^{\star *} \\
(.0004)\end{array}$ & & & & & $\begin{array}{r}-.002^{*} \\
(.001)\end{array}$ & $\begin{array}{r}-.002^{\star} \\
(.001)\end{array}$ \\
\hline \multicolumn{9}{|l|}{ Ethnic } \\
\hline fractionalization & & & $\begin{array}{c}.002 \\
(.001)\end{array}$ & $\begin{array}{l}.002 \\
(.001)\end{array}$ & & & $\begin{array}{l}.004^{*} \\
(.002)\end{array}$ & $\begin{array}{l}.004^{* *} \\
(.002)\end{array}$ \\
\hline Press freedom & & & & & $\begin{array}{l}.006^{* *} \\
(.002)\end{array}$ & $\begin{array}{r}.006^{*} \\
(.002)\end{array}$ & $\begin{array}{r}.005^{*} \\
(.002)\end{array}$ & $\begin{array}{r}.005^{\star} \\
(.002)\end{array}$ \\
\hline Constant & $\begin{array}{l}.60^{\star *} \\
(.23)\end{array}$ & $\begin{array}{l}.60^{\star *} \\
(.24)\end{array}$ & $\begin{array}{l}1.02^{*} \\
(.27)\end{array}$ & $\begin{array}{l}1.03^{*} \\
(.28)\end{array}$ & $\begin{array}{l}.41 \\
(.43)\end{array}$ & $\begin{array}{c}.42 \\
(.44)\end{array}$ & $\begin{array}{c}.13 \\
(.31)\end{array}$ & $\begin{array}{c}.12 \\
(.32)\end{array}$ \\
\hline \multicolumn{9}{|l|}{$\begin{array}{r}\text { Random variance } \\
\text { components: }\end{array}$} \\
\hline Sd (cons.) & $\begin{array}{c}2.58 \mathrm{e}-12 \\
(1.19 \mathrm{e}-10)\end{array}$ & & $\begin{array}{c}3.11 \mathrm{e}-12 \\
(1.31 \mathrm{e}-10)\end{array}$ & & $\begin{array}{c}1.64 e-11 \\
(7.13 e-11)\end{array}$ & & $\begin{array}{c}5.72 \mathrm{e}-13 \\
(2.89 \mathrm{e}-11)\end{array}$ & \\
\hline Sd (residual) & $.07(.045)$ & & $.08(.05)$ & & $.07(.01)$ & & $.07(.04)$ & \\
\hline Obs & 180 & 180 & 180 & 180 & 180 & 180 & 180 & 180 \\
\hline Countries & 20 & 20 & 20 & 20 & 20 & 20 & 20 & 20 \\
\hline$R^{2}$ & & .60 & & .57 & & .65 & & .67 \\
\hline Wald model test & & & & & & & & \\
\hline $\operatorname{Pr}\left(\chi^{2}\right)$ & 333.4 & & $2,772.9$ & & 227.2 & & $1,348.6$ & \\
\hline Log likelihood & & & & & & & & \\
\hline (iteration 0 ) & .911 & & .869 & & .966 & & 1.006 & \\
\hline Log likelihood & 1.129 & & 1.083 & & 1.180 & & 1.221 & \\
\hline Estimation method & MLM & WLS & MLM & WLS & MLM & WLS & MLM & WLS \\
\hline
\end{tabular}

Note. The dependent variable is the percent of single bidders. All models include (not shown): PPP per capita (logged, 2011), social trust, population density (logged) and percent of women in parliament. Other regional level variables from table 4 were dropped due to insignificance. WLS estimation reports country clustered, robust standard errors in parentheses; in such models the regional level observations are weighted by the population. MLM is estimated with the same regional controls as the WLS models and allows for random country intercepts. Units weighted by population and country-clustered standard errors are in parentheses. MLM = multilevel modeling; PPP = purchasing power parity; WLS = weighted least squares.

${ }^{*} p<.05$.

$* * p<.01$.

the democratic accountability of political officials — such as the introduction of open-list electoral systems and party primaries in corruption-ridden countries (Buck 2013). Likewise, the massive anticorruption rallies that have taken place since 2011 in Greece, Spain, Italy, Israel, India, Brazil, Mexico, Chile, Guatemala, and Honduras, among other countries, demand "real democracy" and have improved accountability for a class of political representatives that are seen as benefiting special business interests (Kulish 2011). Nevertheless, in light of the results presented in this article, there are good reasons for proposing reforms that focus on the accountability of nonpolitical public officials. How we select bureaucrats, and which career incentives the structure gives them, are of critical importance for understanding corruption. In particular, the implication of our findings is that reforms should be aimed not at making bureaucratic agents as responsive as possible to their political principals but, quite the contrary, at making them autonomous.

Second, shifting from a staff policy mostly based on atwill political appointments to one based on merit criteria would probably also lead to notable efficiency gains. The effects identified in this article are substantial. For instance, moving all regions below the 90th percentile of meritocracy to that threshold - that is, making them similar to YorkshireHumber or Baden-Wüttemberg-would lower corruption risks by 7.5 to 11.6 percentage points in terms of single- 
bidding incidence. In turn, this would decrease procurement costs by roughly 0.5 to 0.8 percentages across Europe, which is equal to 13-20 billion EUR savings per year in 2010 prices.

\section{ACKNOWLEDGMENTS}

We thank Amy Alexander, Philippe Bezes, Marcia Grimes, Gábor Kocsis, David Lewis, Rafael Jiménez Asensio, Phil Keefer, Johannes Lindvall, Adela Mesa, Marina Nistotskaya, Carles Ramió, Bo Rothstein, Jan Rovny, Brigitte Seim, Andes Sundell, Daniel Treisman, Sofia Wickberg, Andy Whitford, the editor of $J O P$, the anonymous reviewers, and many others for their help and comments on earlier drafts of the article. We also thank Janet Vesterlund for language editing. Finally, we owe special thanks to the Quality of Government Institute at the Department of Political Science, University of Gothenburg.

\section{REFERENCES}

Acemoglu, Daron, and James Robinson. 2012. Why Nations Fail: The Origins of Power, Prosperity, and Poverty. New York: Crown Business.

Alesina, Alberto, Arnaud Devleeschauwer, William Easterly, Sergio Kurlat, and Romain Wacziarg. 2003. "Fractionalization." Journal of Economic Growth 8 (2): 155-94

Andersson, Stefan, and Paul Heywood. 2009. "The Politics of Perception: Use and Abuse of Transparency International's Approach to Measuring Corruption." Political Studies 57 (4): 746-67.

Andrews, Josephine T., and Gabriella R. Montinola. 2004. "Veto Players and the Rule of Law in Emerging Democracies." Comparative Political Studies 37 (1): 55-87.

Becker, Sascha, and Ludger Woessmann. 2009. "Was Weber Wrong? A Human Capital Theory of Protestant Economic History." Quarterly Journal of Economics 124 (2): 531-96.

Boix, Carles, and Susan Stokes. 2003. "Endogenous Democratization." World Politics 55 (4): 517-49.

Brunetti, Aymo, and Beatrice Weder. 2003. “A Free Press Is Bad News for Corruption.” Lournal of Public Economics 87 (7): 1801-24.

Bryan, Mark, and Stephen Jenkins. 2016. "Multilevel Modeling of Country Effects: A Cautionary Tale.” European Sociological Review 32 (1): 3-22.

Buck, Tobias. 2013. "Politicians Pilloried amid Spanish Sleaze." Financial Times, August 2.

Charron, Nicholas, and Victor Lapuente. 2013. "Why Do Some Regions in Europe Have a Higher Quality of Government?" Journal of Politics 75 (3): $567-82$.

Charron, Nicholas, Carl Dahlström, and Victor Lapuente. 2016. "Measuring Meritocracy in the Public Sector in Europe: A New National and Sub-national Indicator." European Journal on Criminal Policy and Research 22 (3): 369-97.

Charron, Nicholas, Lewis Dijkstra, and Victor Lapuente. 2015. "Mapping the Regional Divide in Europe: A Measure for Assessing Quality of Government in 206 European Regions." Social Indicators Research 122 (2): 315-46

Charron, Nicholas, and Bo Rothstein. 2014. "Social Trust, Quality of Government and Ethnic Diversity: An Empirical Analysis of 206 Regions in Europe." QoG Working Paper 2014:20.

Coviello, Decio, and Mario Mariniello. 2014. "Publicity Requirements in Public Procurement: Evidence from a Regression Discontinuity Design.” Journal of Public Economics 109 (January): 76-100.
Dahlström, Carl, Victor Lapuente, and Jan Teorell. 2012. "The Merit of Meritocratization Politics, Bureaucracy, and the Institutional Deterrents of Corruption." Political Research Quarterly 65 (3): 656-68.

Fazekas, Mihály, and Gábor Kocsis. 2015. Uncovering High-Level Corruption: Cross-National Corruption Proxies Using Government Contracting Data. GTI Working paper, GTI-WP/2015:02, Government Transparency Institute, Budapest.

Fukuyama, Francis. 2011. The Origins of Political Order: From Prehuman Times to the French Revolution. New York: Profile.

Frant, Howard. 1993. "Rules and Governance in the Public Sector: The Case of Civil Service." American Journal of Political Science 37 (4): 990-1007.

Galbraith, James, and Enrique Garcilazo. 2005. "Pay Inequality in Europe 1995-2000: Convergence between Countries and Stability Inside." European Journal of Comparative Economics 2 (2): 139-75.

Geddes, Barbara. 1991. "A Game Theoretic Model of Reform in Latin American Democracies.” American Political Science Review 85 (2): 37192.

Gennaioli, Nicola, Rafael La Porta, Florencio Lopez-de-Silanes, and Andrei Shleifer. 2011. Human Capital and Regional Development. Cambridge, MA: National Bureau of Economic Research.

Gingerich, Daniel. 2013. Political Institutions and Party-Directed Corruption in South America: Stealing for the Team. Cambridge: Cambridge University Press

Goldstein, Harvey. 2011. Multilevel Statistical Models. New York: Wiley.

Goodnow, Frank J. 1900. Politics and Administration. New York: Macmillan.

Greenaway, John. 2004. "Celebrating Northcote/Trevelyan: Dispelling the Myths." Public Policy and Administration 19 (1): 1-14.

Gürtel, Caso. 2014. "En AENA había orden 'de contactar con Correa desde que el PP ganó las elecciones.'” Cadena SER, December 15.

Haining, R. 2003. Spatial Data Analysis: Theory and Practice. Cambridge: Cambridge University Press.

Henderson, Jeffrey, David Hulme, Hossein Jalilian, and Richard Phillips. 2007. "Bureaucratic Effects: 'Weberian' State Agencies and Poverty Reduction.” Sociology 41 (3): 515-32.

Hernández, José A. 2015. “The Three-Percent Problem: Catalan Premier Says He Is 'Big Game Target' in Wake of Arrests.” El País, October 21.

Hernández, Mauricio. 2010. "Pais Vasco.” In Nicholas Charron, Victor Lapuente, and Bo Rothstein, eds., "Measuring the Quality of Government in the EU and Sub-national Variation." Report for the European Commission Directorate-General Regional Policy and Directorate Policy Development, EU 2010, Brussels.

Hollyer, James. 2011. Merit Recruitment in 19th and Early 20th Century European Bureaucracies. Minneapolis: Department of Politics, University of Minnesota.

Huang, Francis L. 2016. "Alternatives to Multilevel Modeling for the Analysis of Clustered Data." Lournal of Experimental Education 84 (1): 175-96.

Jiménez-Asensio, Rafael. 2013. "Ética pública, política y alta administración: Los códigos éticos como vía para reforzar el buen gobierno, la calidad democrática y la confianza de la ciudadanía en las instituciones." Revista Vasca de Gestión de Personas y Organizaciones Públicas 5:45-67.

Jong-sung, You, and Sanjeev Khagram. 2005. "A Comparative Study of Inequality and Corruption.” American Sociological Review 70 (1): 136-57.

Jos, Philip H., and Mark E. Tompkins. 2004. "The Accountability Paradox in an Age of Reinvention: The Perennial Problem of Preserving Character and Judgment." Administration and Society 36 (3): 255-81.

Kassam, Ashifa. 2014. "Spanish Authorities Arrest 51 Top Figures in Anticorruption Sweep.” Guardian, October 27. 
Keefer, Philip. 2007. "Clientelism, Credibility, and the Policy Choices of Young Democracies." American Journal of Political Science 51 (4): 80421.

King, Gary, Robert Keohane, and Sidney Verba. 1994. Designing Social Inquiry. Princeton, NJ: Princeton University Press.

Kitschelt, Herbert, and Steven I. Wilkinson. 2007. Patrons, Clients, and Policies: Patterns of Democratic Accountability and Political Competition. Cambridge: Cambridge University Press.

Kopecký, Petr, and Gerardo Scherlis. 2008. "Party Patronage in Contemporary Europe." European Review 16 (3): 355-71.

Kulish, Nicholas. 2011. "As Scorn for Vote Grows, Protests Surge around Globe." New York Times, September 27.

Kurtz, Marcus, and Schrank, Andrew. 2007. "Growth and Governance: Models, Measures, and Mechanisms." Lournal of Politics 69 (2): 538-54.

La Porta, Rafael, Florencio Lopez-de-Silanes, Andrei Shleifer, and Robert Vishny. 1999. "The Quality of Government." Lournal of Law, Economics, and Organization 15:222-79.

Lipset, Seymour M. 1960. Political Man: The Social Basis of Modern Politics. New York: Doubleday.

Llera, F. 2000. Gobierno y administración en Euskadi, PANIAGUA J. Gobierno y Administración en las Comunidades Autónomas. Madrid: Tecnos.

Mesa, Adela. 2000. "La politización de las estructuras administrativas de las Comunidades Autónomas.” Revista Española de Ciencia Política 2:211-35.

Miller, Gary J. 2000. "Above Politics: Credible Commitment and Efficiency in the Design of Public Agencies." Lournal of Public Administration Research and Theory 10 (2): 289-328.

Miller, Gary, and Andrew B. Whitford. 2007. "The Principal's Moral Hazard: Constraints on the Use of Incentives in Hierarchy." Journal of Public Administration Research and Theory 17 (2): 213-33.

Nath, Anusha. 2015. "Bureaucrats and Politicians: How Does Electoral Competition Affect Bureaucratic Performance?" Working paper 269, Institute of Economic Development, Boston University.

North, Douglass, John Wallis, and Barry Weingast. 2009. Violence and Social Orders: A Conceptual Framework for Interpreting Recorded Human History. New York: Cambridge University Press.

Olaya, Vicente G. 2013 "Los visitadores de la trama Gürtel." El País, July 26.

Olsen, Johan P. 2006. "Maybe It Is Time to Rediscover Bureaucracy." Journal of Public Administration Research and Theory 16 (1): 1-24.

Olsen, Johan P., and James G. March. 2008. "The Logic of Appropriateness." In Martin Rein, Michael Moran, and Robert E. Goodin, eds., Handbook of Public Policy. Oxford: Oxford University Press.

Persson, Torsten, and Guido Tabellini. 2003. The Economic Effects of Constitutions. Cambridge, MA: MIT Press.

Pew Research Center. 2012. "Assessing the Representativeness of Public Opinion Surveys." http://www.people-press.org/files/legacy-pdf/Assessing\%20the \%20Representativeness\%20of\%20Public\%20Opinion\%20Surveys.pdf (accessed September 2015).

Piattoni, Simona. 2001. Clientelism, Interests, and Democratic Representation: The European Experience in Historical and Comparative Perspective. Cambridge: Cambridge University Press.
Putnam, Robert, Robert Leonardi, and Raffaella Nanetti. 1993. Making Democracy Work. Princeton, NJ: Princeton University Press.

Rauch, James, and Peter Evans. 2000. "Bureaucratic Structure and Bureaucratic Performance in Less Developed Countries." Lournal of Public Economics 75:49-71.

Rokkan, Stein. 1970. Citizens, Elections, Parties: Approaches to the Comparative Study of the Process of Development. New York: McKay.

Rose-Ackerman, Susan. 1999. Corruption and Government. Cambridge: Cambridge University Press.

Rothstein, Bo. 2011. The Quality of Government: Corruption, Social Trust and Inequality in International Perspective. Chicago: University of Chicago Press.

Rothstein, Bo, and Eric Uslaner. 2005. "All for All: Equality, Corruption, and Social Trust." World Politics 58 (1): 41-72.

Shaxson, Nicholas, and John Christensen. 2014. The Finance Curse: How Oversized Financial Centres Attack Democracy and Corrupt Economies. Chesham: Tax Justice Network.

Snyder, Richard. 2001. "Scaling Down: The Subnational Comparative Method." Studies in Comparative International Development 36 (1): 93-110.

Sundström, Axel. 2013. Women's Local Political Representation within 30 European Countries: A Comparative Data Set on Regional Figures. QoG Working Paper 2013:18.

Swamy, Anand, Stephen Knack, Young Lee, and Omar Azfar. 2001. "Gender and Corruption." Iournal of Development Economics 64 (1): 25-55.

Tabellini, Guido. 2010. "Culture and Institutions: Economic Development in the Regions of Europe." Journal of the European Economic Association 8 (4): 677-716.

Teorell, Jan, Carl Dahlström, and Stefan Dahlberg. 2011. "The QoG Expert Survey Dataset." University of Gothenburg, Quality of Government Institute.

Teorell, Jan, Nicholas Charron, Stefan Dahlberg, Sören Holmberg, and Bo Rothstein. 2013. "The Quality of Government Dataset, version 20Dec13." University of Gothenburg, Quality of Government Institute.

Treisman, Daniel. 2007. "What Have We Learned about the Causes of Corruption from Ten Years of Cross-National Empirical Research?" Annual Review of Political Science 10:211-44.

Uslaner, Eric M., and Bo Rothstein. 2016. "The Historical Roots of Corruption: State Building, Economic Inequality, and Mass Education." Comparative Politics 48 (2): 227-48.

Weber, Max. (1904) 2002. The Protestant Ethic and the Spirit of Capitalism: And Other Writings. New York: Penguin.

Weber, Max. (1922) 1978. Economy and Society. Berkeley: University of California Press.

Wilson, Woodrow. 1887. "Study of Administration." Political Science Quarterly 2:197-222.

Welzel, Christian, and Ronald Inglehart. 2008. "The Role of Ordinary People in Democratization." Journal of Democracy 19 (1): 126-40.

Wängnerud, Lena. 2009. "Women in Parliaments: Descriptive and Substantive Representation." Annual Review of Political Science 12:51-69.

Zack, Paul, and Stephen Knack. 2001. "Trust and Growth." Economic Lournal 111 (1): 295-321. 